\title{
Креатиивнос $\bar{u}$ и конформнос $\bar{u} y$ симболичкој иіри ӣреgиколске gјеце
}

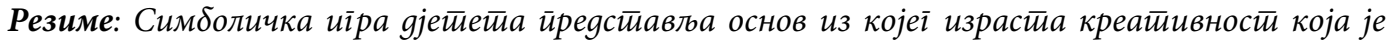
иретеиеча сииваралачких gјела у каснијем животиу, иее основ сазријевана и учеюа које се олвија на сйон-

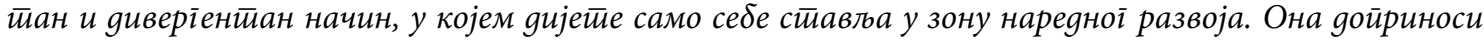

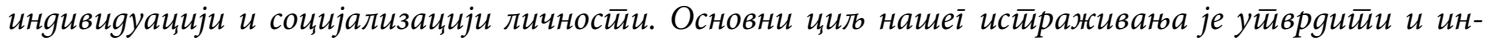

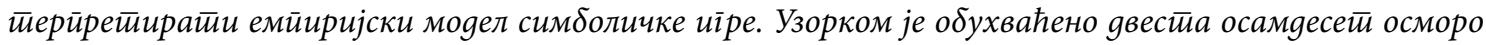

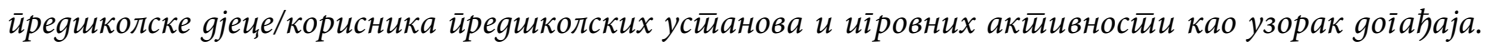

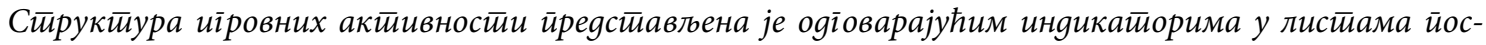

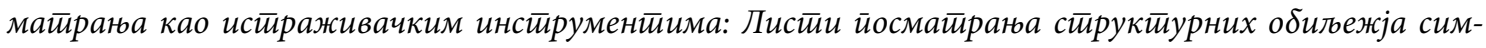

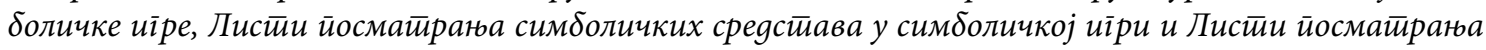
каракиетера ояноса који се оgражавају у симболичкој иіри. Анализом саяржаја извриили смо и анализу

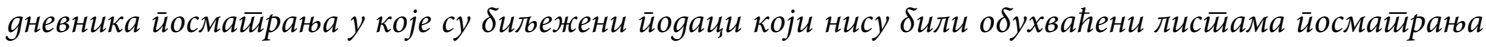
(ойисе саgржаја gјечје иіре, ойисе соиијалних ояноса међу йосмайраном gјецом, ирреферениија саgр-

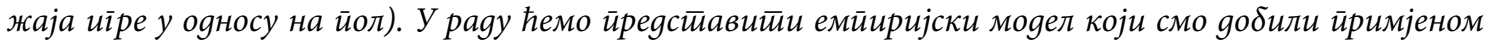

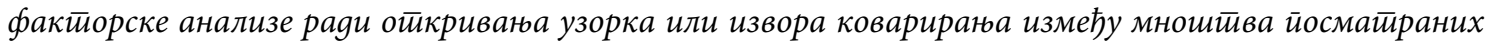

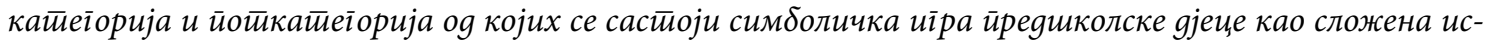

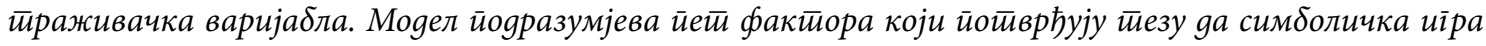

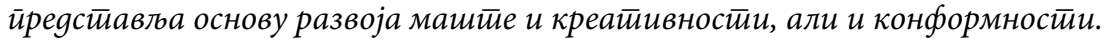

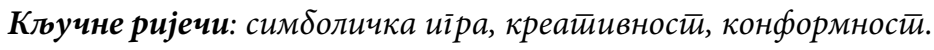

Увод

Процес индивидуације (утемељења личности) одвија се у вјештачкој средини коју зовемо култура. Од појединца се очекује да се прилагоди затеченом стању, али и да га мијења и тиме

1 sanja17_05@yahoo.com хуманизује себе и култивише свијет око себе. Али, издвојивши се из природе, из свог природног стања, човјек се и денатурализује, те, изграђујући културу, губи спонтаност и природност, који су важни елементи креативности. Данас отуђеност напредује брже него икад јер су хуманизација и натурализација човјека у толи- 
ком раскораку да личност постаје артифицијелна. Цивилизација (материјалне вриједности) развија се брже од културе (духовне вриједности). У таквим околностима дјеца добивају на важности. Свако ново дијете је нада и шанса да превазиђемо такву отуђеност, јер са сваким новорођеним дјететом живот почиње изнова. Да би опстао, човјек мора сачувати везу са цјелином свијета, какву има само дијете, и то на једном вишем нивоу, на нивоу еколошке свијести - свијести да је опстанак цијелог људског рода условљен опстанком сваког појединца, свијести о безграничној важности сваке индивидуе као личности, свијести о важности дјетета и дјетињства. Никада није било потребније „вјеровати у природне снаге дјетета“, као што је то чинила Марија Монтесори. „Човек као јединство субјекта и објекта опстаје само у отвореном контексту. Чим контекст затворимо, човјека раздвајамо на субјект и објект. Конформност се не може уочити у спонтаности и интуитивности синкретичког мишљења, при којем особа и предмет посматрања неразлучено егзистирају у конкретном али потпуно отвореном контексту. Човјек осмишљава свој однос према свијету живећи y ogносу са свијетом. Креативност/стваралаштво је у тим околностима омогућено отвореношћу контекста као цјеловитог животног контекста. Због тога је та креативност природна, ничим спутана - оригинална. Она осваја својом наивношћу у којој се преплићу вјера, нада и љубав као исконска својства људског чулног одношења према свијету. Конформност на сцену ступа са рационалношћу и заједно са њом нараста под утицајем развоја цивилизације“ (Bogojević, 2006: 189). У игровном контексту дијете испољава своје стваралачке потенцијале до максимума управо захваљујући његовој отворености. Основа креативности је машта (фикција), која је „заснована на способности нашег мозга да комбинује. У том смислу, све оно што нас окружује и што је човјек створио, сав свијет културе, за разлику од свијета природе - све је то производ људске маште и стваралаштва заснованог на тој машти“ (Vigotski, 2005: 19). Упоредо са развојем симболичке функције, односно способности дјетета да ствара, користи и комбинује симболе, јавља се симболичка игра која, према Виготском, представља рану манифестацију стваралачких способности. Такав свој став он потврђује тврдњом да машта (комбинаторна фантазија) проистиче управо из симболичке игре која је нужна за интелектуални развој дјетета. Симболичка игра дјетета је основ из којег израстају различити облици стваралаштва који се јављају у даљем дјететовом развоју.

У психолошкој литератури примјећујемо (Supek, 1987; Vinikot, 1999; Winer, 2005) да су се питањем креативности највише бавили представници психоаналитичког приступа истраживањима. Велики број психолошких истраживања усмјерен је на проучавање односа креативности с личношћу. Фројд (Freud, 1910), творац психоанализе, говори о постојању конформистичке дјеце (која се касније претварају у одрасле конформистичке појединце) и нонконформистичке дјеце. Док конформистичка дјеца потискују и задржавају своје унутрашње пориве како би се прилагодили захтјевима околине и избјегли сукоб с њом, неконформистичка дјеца су импулсивне природе, склонија непосредном изражавању порива који им долазе из властите личности и, управо захваљујући својој импулсивности и неконформизму, више оригиналне природе и више креативне (Freud, 1910; према: Supek, 1987). Резултати већине других истраживања (Crutchfield, 1965; Barron, 1965; Tyson, 1966; Taylor, 1966) иду у прилог чињеници да су креативни појединци доста сложене личности (Supek, 1987). Супек наглашава „да управо та сложеност црта и њихова повезаност с људским карактером говори у прилог тези да је креативност општа црта људске животности, да она највише зависи од тога колико појединац успијева у односу с околином изразити ту своју животност, своје унутрашње пориве, своје потенцијал- 
не диспозиције“ (Supek, 1987: 49). Виникот сматра да се пуна слобода креативности може остварити само у игрању, а креативност омогућује појединцу да пронађе своје ја. „У игри и једино у игри дијете и одрастао човјек кадри су да буду креативни и да се служе цијелом својом личношћу, а једино у својој креативности појединац открива сопство“ (Vinikot, 1999: 70).

Из жеље да се „уклопе у свијет одраслих“, што је, према Ељкоњину (Eljkonjin, 1990), основна функција игре улога, дијете у њој опонаша одрасле. То остваривање улоге у игри захтјева од дјетета врло сложену активност маште: „оно мора јасно да види у представи шта треба да ради његов јунак у датом тренутку и да планира његове даље радње, да, полазећи од настале ситуације, усмјерава, уопште, развој игре у цјелини. Игра улога осваја дијете, она ствара оно емоционално расположење које је неопходно за стваралаштво, тако да управо у игри дијете најпотпуније и најслободније изражава себе“ (Djačenko i Lavrentjeva, 1984: 104). У симболичким играма или играма улога дијете креира себе и свој свијет. У њима креативност заправо нема граница. Дјеца се у тренутку претварају у принчеве и принцезе, каменчићи постају бомбоне, свијет постаје шарен и бајковит.

\section{Методологија}

Анализа теоријских сазнања и емпиријских показатеља о проблематици која се бави питањима симболичке игре и њеном улогом и значајем у развоју дјетета отворила нам је бројна методолошка питања. Установили смо да симболичка игра предшколске дјеце емпиријски није значајније истраживана код нас. Симболичка игра, у методолошком смислу, представља изузетно сложену истраживачку варијаблу (конструкт) садржану од низа ужих конструката. Отворило нам се и питање: Како конструкт симболичку иіру йреgшколске gјеце превести у индикаторе?

\section{Узорак}

Истраживање је обављено на узорку од двеста осамдесет осморо дјеце/корисника предшколских установа - сто четрдесет три дјевојчице и сто четрдесет пет дјечака узраста од три до шест година. Посматрани су у игри која је била спонтано иницирана од стране саме дјеце, па узорак представљају и игровне активности, и то као узорак догађаја. Наиме, сваку игровну активност посматрачи су узимали као догађај који треба забиљежити. Сваки догађај/игровна активност има своју сложену структуру која је представљена одговарајућим индикаторима у листама посматрања као истраживачким инструментима.

\section{Инстирументии истираживања}

У складу са циљем и предметом нашег истраживања, опредијелили смо се за примјену сљедећих истраживачких инструмента: Листа посматрања структурних обиљежја симболичке игре, Листа посматрања средстава која се користе у симболичкој игри, Листа посматрања карактера односа међу људима који се одражавају у игри дјеце и Протокол за анализу садржаја.

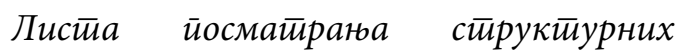
обиљежја симболичке иіре намјењена је посматрању учесталости структурних обиљежја симболичке игре предшколске дјеце. Инструмент садржи пет категорија: аутотеличност (структурно обиљежје игре које нам указује на то да је игра унутрашње мотивисана и самим тим емоционално обојена, те да је у игри важан сам процес играња, а не постизање одређеног циља), дивергентност (обиљежје које потврђује да је игра активност у којој није дефинисан циљ, активност у којој дјеца могу испољити своју креативност, изразити своју маштовитост, изнаћи различите могућности рјешавања одређених проблема, понашати се према различитим обрасцима понашања и др.), фикцију (представља најважније обиљежје симболичке игре јер 
је издваја из осталих врста игровних активности), употребу „мотивисаних“ симбола (симболи игре су великим дијелом „мотивисани“, што значи да постоји одређена веза између објекта-симбола и реалног објекта) и метафоричност (метафоричност игре се огледа у преименовању предмета уз присутну свијест о тој замјени, употреба језика на метафоричан начин има свој почетак у симболичкој игри предшколске дјеце). Структурна обиљежја симболичке игре посматрана су кроз четири поткатегорије које представљају облике дјечје игре (сам, у пару, мања група и велика група).

Лисииа иосмайрағьа симболичких среgсйава у симболичкој иіри намјењена је посматрању учесталости испољавања симболичких средстава која се јављају у симболичкој игри. Основу за конструисање ове листе посматрања представљају резултати до којих је, у свом истраживању употребе симболичких средстава, дошла Мирјана Дуран (Duran, 1995). На основу анализе података о симболичкој игри сто двадесеторо дјеце узраста од пет до шест година, Дуранова је описала и идентификовала репертоар симбола које користе дјеца у симболичкој игри или игри улога као сложеном семиотичком систему. На основу њених истраживања могуће је идентификовати сљедеће основне врсте симболичких средстава које имају сигнификантну функцију: симболички објекти замјене (представљају знакове или симболе који стоје умјесто неког другог објекта, нпр. дијете храни лутку штапићем/ кашиком, ставља пред њу каменчиће/шницле, намјешта је да спава у малу кутију/ креветић), симболичке радње (дјеца у игри репродукују предметне радње које су видјели или усвојили од одраслих - купање, храњење; моторичка предметна радња у игри има двоструко значење јер представља оно што јесте по себи и оно што симболизује), ментални репрезентант (у симболичкој игри дјетета јављају се менталне слике као иконички симболи, нпр. уколико дјечак који игра улогу ватрогасца на објекат који у игровном контексту означава запаљену кућу из објекта који представља ватрогасно возило сипа воду коју не видимо, можемо закључити постојање менталног репрезентанта) и говор (говор као основно средство комуникације дијете у игри удружује са другим симболичким средствима и уз помоћ њих репрезентује свој доживљај стварности). Наш инструмент садржи седам категорија: симболички објекти замјене, моторичке предметне радње, покрети дијелова тијела и држање тијела, самоодносне радње, ментални репрезентант, говор као значењско средство и говор као паралингвистичко средство.

Каракиере односа међу људима који се оgражава у иіри gјеце јесте листа посматрања коју је на основу Ељкоњинових теоретских поставки креирао Светозар Богојевић (Bogojević, 2010). Извршена је њена допуна и адаптација потребама нашег истраживања. Каракӣер ogноса међу тьудима који се одражава у иіри gјеце је листа посматрања која садржи десет категорија: дијете, сарадња, узајамна помоћ, подјела рада, брига и пажња, симпатије, господарење, непријатељство, грубост и такмичење.

Анализом садржаја извршили смо и анализу дневника посматрања у којим су биљежени подаци који нису били обухваћени листама посматрања, а били су важни за квалитативну обраду података (ойuсе саgржаја gјечје иіре, ойuce coиијалних олноса међу иосмайраном дјецом и начине разрјешаваюа конфликайа, ирреферениија саgржаја у оgносу на йол). У ту сврху кориштен је Пройокол за анализу саяржаја.

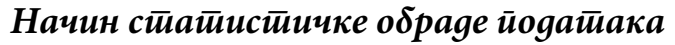

Симболичка игра предшколске дјеце, као сложена истраживачка варијабла, садржана је од низа ужих конструката који се даље могу разложити у мноштво индикатора. Управо зато, приступили смо факторској анализи као скупу статистичких поступака који омогућује от- 
кривање узрока или извора коварирања (фактора) између мноштва посматраних категорија и поткатегорија (манифестних варијабли) које смо дефинисали у инструментима.

Будући да је сваку корелациону матрицу прије факторизације потребно подвргнути барем једном статистичком тесту значајности (Fulgosi, 1988), у ту сврху примјенили смо два теста: Кајзер-Мајер-Олкинов показатељ адекватности узорка (КМО) и Бартлетов тест сферичности. На КМО тесту утврдили смо вриједност индекса $\mathrm{K}=0,83$, који указује да су добијени подаци погодни за примјену факторске анализе. Прецизније, тест указује да је велики дио варијансе испитиваних варијабли увјетован заједничким факторима. Такође, Бартлетов тест се показао статистички значајним (статистички значајним $\left(\chi^{2}=6526,51 ; \mathrm{df}=630\right.$; Sig. 0,01). Овај тест нам указује да се корелациона матрица манифестних варијабли статистички значајно разликује од матрице идентитета.

Иако је факторска анализа могла бити спроведена коришћењем више метода, опредјелили смо се за методу главних компоненти (енг. principal component analysis, PCA), с обзиром на то да је анализа главних компоненти боља опција код уобичајених сажимања скупа података (Tabachnick \& Fidell, 2007; види код: Pallant, 2009).

Сљедећи изазов био је одређивање броја фактора. Критерији за екстракцију броја фактора били су Кајзер-Гутманов критериј (KaiserGuttman) за вриједност карактеристичног ко- ријена (вриједност најмање 1), Кателов тест одрона (Cattell scree plot), минимум 50\% објашњене варијансе и што мањи број фактора (парсимонија). Поред комбинације наведених критерија, битан нам је био још један, а то је интерпретабилност факторског модела. Примјењујући поменуте критерије, добили смо десетак различитих модела који задовољавају елементарне статистичко-формалне услове. Тако, на примјер, само према критерију својствене вриједности добили смо модел који има чак десет компоненти/фактора, али је постојао проблем како их интерпретирати. С друге стране, Кателов тест одрона указивао је на упола мање фактора, тек четири до шест. Такође, искористили смо опцију у статистичком програму диригованог одређивања броја фактора. Резултат примјене ових критеријума и накнадних аналитичких ротација јесу три модела, од којих ће један бити интерпретиран у овом раду.

\section{Резултати истраживања}

Наш емпиријски модел потврђује тезу да је креативност битно својство симболичке игре, а настојат ћемо га објаснити разматрањем пи-

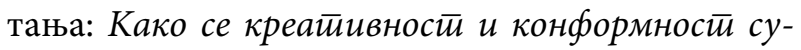
cpeћy y uірu? У Табели 1 уочавамо да у овом моделу имамо пет фактора, који подједнако, с изузетком петог фактора, учествују у објашњењу укупно 56,70\% испитиване појаве.

Приказани резултати указују да је симболичка игра дјететов простор у коме су задржа-

\section{Табела1. Емӣиријски (факйорски) модел симболичке иіре}

\begin{tabular}{|l|c|c|c|}
\hline \multicolumn{1}{|c|}{ Компоненте или фактори } & $\begin{array}{c}\text { Својствена } \\
\text { вриједност }\end{array}$ & $\begin{array}{c}\text { Постотак } \\
\text { објашњене варијансе }\end{array}$ & $\begin{array}{c}\text { Кумулативни постотак обја- } \\
\text { шњене варијансе }\end{array}$ \\
\hline Темељно игре & 5,08 & 14,12 & 14,12 \\
\hline Примарна креативност & 4,63 & 12,86 & 26,98 \\
\hline Секундарна креативност & 4,38 & 12,18 & 39,16 \\
\hline Зачеци конформности & 3,91 & 10,86 & 50,02 \\
\hline Конформност & 2,41 & 6,68 & 56,70 \\
\hline
\end{tabular}


не примарна и секундарна креативност. Симболичка игра не искључује ни конформност иако је она у другом плану у односу на креативност.

У ротираној матрици факторске структуре (Табела 2) приказана су факторска засићења. Крећу се у распону од 0,39 до 0,86 . Терстонов иде- ал једноставне структуре највише је нарушен у петом фактору, јер су ту максимална засићења најнижа $(0,69)$, а истовремено имамо највећи број засићења $\geq 0,30$ који не припада том фактору.

Први фактор - Темельно иіре - објашњава $14,12 \%$ тоталне варијансе. Варијабле које чине структуру првог фактора представљају оно те-

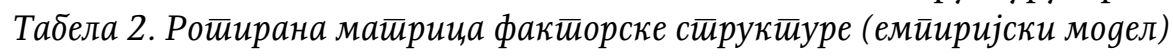

\begin{tabular}{|c|c|c|c|c|c|}
\hline \multirow[t]{2}{*}{ Манифестне варијабле } & \multicolumn{5}{|c|}{ Компоненте } \\
\hline & 1 & 2 & 3 & 4 & 5 \\
\hline Симболички објекти замјене & 0,77 & & & & \\
\hline Сарадња & 0,77 & 0,32 & & & \\
\hline Подјела рада & 0,75 & & & & \\
\hline Узајамна помоћ & 0,69 & 0,34 & & & \\
\hline Покрети дијелова тијела и држање тијела & 0,61 & & & & \\
\hline Ментални репрезентант & 0,59 & & & & \\
\hline Дивергентност (мања група) & 0,57 & & 0,30 & & \\
\hline Симпатије & 0,51 & 0,31 & & 0,32 & \\
\hline Употреба „мотивисаних“ симбола (сам) & & 0,86 & & & \\
\hline Дивергентност (сам) & & 0,73 & & & \\
\hline Метафоричност (сам) & & 0,68 & & & \\
\hline Употреба „мотивисаних“ симбола (у пару) & & 0,60 & 0,31 & & \\
\hline Такмичење & & 0,59 & & & \\
\hline Фикција (у пару) & & 0,58 & & 0,33 & \\
\hline Фикција (сам) & 0,50 & 0,58 & & & \\
\hline Аутотеличност (сам) & & 0,57 & & 0,48 & \\
\hline Метафоричност (у пару) & & 0,39 & & & \\
\hline Метафоричност (већа група) & & & 0,82 & & \\
\hline Употреба „мотивисаних“" симбола (већа група) & & & 0,79 & & \\
\hline Фикција (већа група) & & & 0,78 & & \\
\hline Дивергентност (већа група) & & & 0,67 & & \\
\hline Метафоричност (мања група) & & & 0,66 & & \\
\hline Употреба „мотивисаних“ симбола (мања група) & & 0,36 & 0,52 & & \\
\hline Говор као паралингвистичко средство & & & 0,48 & & \\
\hline Аутотеличност (мања група) & 0,31 & & 0,47 & & \\
\hline Фикщија (мања група) & 0,46 & & 0,47 & & \\
\hline Дивергентност (у пару) & & & & 0,69 & \\
\hline Говор као значењско средство & & 0,30 & & 0,69 & \\
\hline Моторичке предметне радње & 0,34 & & & 0,68 & \\
\hline Аутотеличност (у пару) & & 0,39 & & 0,68 & \\
\hline Аутотеличност (већа група) & & & 0,49 & 0,65 & \\
\hline Самоодносне радње & 0,48 & & & 0,57 & \\
\hline Брига и пажња & 0,47 & & & 0,48 & \\
\hline Господарење & & & & & 0,83 \\
\hline Непријатељство & & & & & 0,81 \\
\hline Грубост & & & & & 0,77 \\
\hline
\end{tabular}

Найомена: засићеюа исйоg 0,30 су, раgи иреілеяносии, избачена из тиабеле. 
мељно игре. Првобитна игровна активност дјетета је фиксација на одређени предмет из вањског окружења. То дјететово „стапање“ с одрећеним предметом понекад може створити афективну везаност дјетета за одређени предмет (омиљена играчка, „прелазни објект“...). Након што га фиксира, дијете кроз сензорно-моторичку активност почиње њиме да овладава. Након овладавања одбацује га и враћа у вањштину. Иако је њиме овладало, исти премет може изнова бити прихваћен и замјећен од стране дјетета. Виникот сматра да у првобитној игровној активности дјетета највећу улогу има мајка или особа која има улогу мајке. Према њему, игра није у унутрашњем психичком свијету нити је у вањском свијету, који припада сфери не-ја, већ се налази у „потенцијалном простору“ који се налази између њих и има свој почетак у односу између мајке и дјетета. Тај однос подразумјева повјерење и представља основу изградње даљњих позитивних социјалних односа. „Бебино повјерење у мајчину поузданост, и отуда у поузданост осталих људи и ствари, омогућава одвајање не-ја од ја. Истовремено, могло би се рећи да је одвајање избјегнуто попуњавањем потенцијалног простора креативним играњем, употребом симбола и осталим што на крају доприноси културном животу“ (Vinikot, 1999: 130). Након што дијете овлада одређеним предметом и одбаци га, мајка му га поново враћа назад, допуштајући дјетету да се изнова осјети као извор акције. Мајка интервенише док год је то потребно, чинећи дјетету свијет расположивим. Прва манифестација игровне активности дјетета је способност употребе једног предмета умјесто другог. Употреба једног предмета умјесто другог и репродуковање појединих радњи су предуслов за развијену симболичку игру или игру улога. Иако се у темељном игре дјеца најчешће играју сама или у присуству друге особе, у њој преовладавају позитивни социјални односи као што су сарадња, узајамна помоћ, симпатије, подјела рада. Паралелно са узрастом, дјеца теже успостављању односа са другом дјецом с којом настоје подјелити своје маштарије и свој замишљени свијет на начин који је својствен само дјеци или одређеној индивидуи.

Наш други фактор, који смо назвали При-

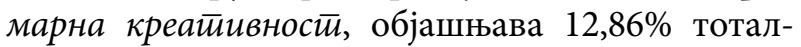
не варијансе. Након што дијете довољно овлада предметима и стекне осјећај сигурности и повјерења, оно почиње да се игра самостално или у присуству друге особе. Играјући се, оно ствара свој замишљени свијет комбинујући различите елементе свог искуства. Основу садржаја дјететове фикције чине ејдетске слике. „Мало дијете је ејдетик у том смислу што његова сјећања, његова машта и његово мишљење још непосредно репродукују конкретни опажај у свој пуноћи доживљаја и свом богатсву конкретних детаља, са живошћу као код халуцинација“(Vigotski, 1996). У својој фикцији дијете чини све оно што није кадро у реалном свијету. Његове креације му дају осјећај вјере и наде у своје моћи. Дијете надиграва само себе стављајући испред себе увијек нове захтјеве. Употреба „мотивисаних“ симбола и метафорични говор су саставни дио дјететове фикције. Напросто, израстају из ње градећи симболичку игру дјетета као прву манифестацију стваралачких способности.

Трећи фактор - Секундарна креатиивности - објашњава 12,17\% тоталне варијансе. Дјететова фикција је првобитно усмјерена на одређене предмете које дијете користи у игри на најразличитије начине. Употреба „мотивисаних“ симбола доприноси грађењу богатијих и разноврснијих представа дјетета, што уједно доприноси и развоју маште. У симболичкој игри дијете себи приписује и различите улоге, а само њихово остваривање у игри ставља га у позицију максималног ангажовања својих стваралачких потенцијала. Да би одиграло одређену улогу, дијете претходно мора измаштати, створити јасне представе о начину њеног одигравања. Кроз метафоричност и невербалну и вербалну комуникацију дијете свој замишљени свијет дијели са другом дјецом. Идеје које се појављују у фикцији сада се дијеле са другима, а то подразумјева потребу њиховог усагла- 
шавања. Игра постаје интенционална, њен садржај је прецизиран. Тим усмјеравањем ка циљу она не губи на спонтаности, већ од дивергентности мишљења креће ка његовој конвергентности.

Четврти фактор - Зачеиц конбормностии - објашњава 10,85\% тоталне варијансе. Паралелно с узрастом, игра дјетета све је више окренута социјалним значењима. Дијете има потребу изразити своју креативност другима. Стога у одигравање одређених радњи и улога „увлачи“ другу дјецу градећи с њима све сложеније игровне структуре. У том смислу, говор као значењско средство има важну улогу у групном усаглашавању. У заједничкој игри дјеце првенствено преовладавају позитивни социјални односи, формирани на узајамном повјерењу.

Пети фактор - Конформносй - објашњава 6,68\% тоталне варијансе. Њега конституишу варијабле које представљају негативне социјалне односе. У симболичкој игри дјеца проучавају међуљудске односе и припремају се за каснији друштвени живот који подразумјева прихватање друштвених норми и правила. Њихови међусобни односи у појединим тренуцима по аутоматизму бивају насилни. У садржају дјечје игре одражавају се дјететови унутрашњи конфликти. Да би дијете схватило и у потпуности уживало у позитивним социјалним односима, оно претходно мора проживјети и негативне социјалне односе. Понекад су негативни социјални односи које дијете манифестује у игровном контексту само пуки одраз дјететове стварности. Дијете је у основи социјално биће које тежи развијању позитивних социјалних односа. Управо је то разлог због којег се дјеца која одрастају уз брата или сестру и која проводе доста времена с вршњацима лакше уклапају у друштво. Ма колико наглашавали значај креативности, ипак, треба рећи да без конформизма нема успјешне социјализације. Његов значај је нарочито битан у прихватању друштвених норми и правила, а њихова прихваћеност се најбоље огледа у контроли: господарење, непријатељства и грубости.

\section{Закључак}

Наш изведени емпиријски модел који објашњава 56,70\% варијансе игре потврђује тезу да симболичка игра има непроцјењиву вриједност и представља основу развоја маште и креативности, али и конформности. Сам развој стваралачких потенцијала зависи од „начина култивисања дјечје игре, те он мора да буде у функцији основних способности и својстава стваралачке личности: отворености према искуству, флексибилности, радозналости, преданости, ризику открића и проналаска, усхићења ..." (Marjanović, 1975: 192). Такав однос подразумјева одрасле који су „посредници“ и „партнери“ у дјечијој игри јер „правилно и научно схваћено васпитање уопште не подразумјева вјештачко наметање дјеци потпуно страних идеала, осјећања или расположења. Правилно васпитање састоји се у томе да пробуди у дјеци оно што у њима постоји, да помогне да се то развије и усмјери тај развој у одређеном смјеру“ (Vigotski, 1996: 56). Гушење креативности на раном узрасту за посљедицу има гушење креативности до краја живота. С друге стране, подршка развоју креативних потенцијала које дијете носи у себи рођењем представља претечу стваралачких дјела у каснијем животу.

Захваљујући отворености игровног контекста, који је једино могућ у симболичкој игри, дијете своје ја смјешта у позицију која му одговара трансформишући на тај начин себе и свијет око себе. На основу анализе нашег изведеног емпиријског модела можемо закључити да прва три фактора (темељно игре, примарна креативност, секундарна креативност) представљају најдубљи ниво, гдје је симболизација окренута унутрашњем и још је у функцији индивидуације, док четврти и пети фактор (зачеци конформности, конформност) представљају симбол окренут спољашњем, социјалним значењима и комуникацији, што указује на процес социјализације.

Позитивно подстицање и култивисање симболичке игре или игре улога, поред пружања 
стимулативног окружења, стварања услова у којима дијете има широк репертоар симболичких средстава, упознавања дјеце са разним сферама људског живота, подразумјева, прије све- га, пружање дјетету позитивних узора и образаца понашања, које ће оно кроз игровни контекст усвојити и трајно задржати у својој личности.

\section{Литература}

- Bogojević, S. (2006). Kompleks fleksibilnosti. Naša škola, 3-4, 181-203.

- Bogojević, S. (2010). Karakter odnosa među ljudima koji se odražava u igri djece. Neobjavljen instrument.

- Valsiner, J. (1997). Čovjekov razvoj i kultura. Beograd: Zavod za udžbenike i nastavna sredstva.

- Vigotski, L. S. (1996). Dječija psihologija. Sabrana djela VI. Beograd: Zavod za udžbenike i nastavna sredstva.

- Vigotski, L. S. (2005). Dječja mašta i stvaralaštvo. Beograd: Zavod za udžbenike i nastavna sredstva.

- Vinikot, D. V. (1999). Igranje i stvarnost. Beograd: Zavod za udžbenike i nastavna sredstva.

- Djačenko, O. M., Lavrantjeva, T. V. (1998). Psihički razvoj predškolske djece. Beograd: Zavod za udžbenike i nastavna sredstva.

- Duran, M. (1995). Dijete i igra. Jastrebansko: Naklada slap.

- Eljkonjin, D. B. (1990). Psihologija dječje igre. Beograd: Zavod za udžbenike i nastavna sredstva.

- Fulgosi, A. (1988). Faktorska analiza. Zagreb: Školska knjiga.

- Marjanović, A. (1975). Igra i stvaralaštvo. Predškolsko dete, 1-2, 180-193.

- Pallant, J. (2009). SPSS priručnik za preživljavanje: postupni vodič kroz analizu podataka pomoću SPSS-a za Windows (verzija15). Beograd: Mikro knjiga.

- Supek, R. i saradnici (1987). Dijete i kreativnost. Zagreb: OOUR Globus.

- Winner, E. (2005). Darovita djeca: mitovi i stvarnost. Zagreb: Ostvarenje d.o.o.

\section{Summary}

Symbolic play of a child is a basis creativity is grown from and this is a forerunner of creative works in further life, and the basis for maturation and learning which is occurring in spontaneous and divergent way in which a child puts himself-herself into the zone of approximate development. This contributes to individualization and socialization of personality. The basic aim of our research is determination and interpretation of the empirical model of a symbolic play. The sample included 288 pre-school children attending kindergartens and activities as an occurrence sample. Structure of playing activities was represented by appropriate indicators in the lists of observing as research instruments: list of observing structure features of symbolic play, list of observing symbolic means in symbolic play and the list of observing character of relations referring to the symbolic play. We have done the analysis of the review log by the analysis of contents, concerning recorded data which were not enhanced in the observation lists (description of contents of children's play, description of social relations between the observed children, preference of contents of play regarding the gender of children). In the paper, we are going to present an empirical model which we got by application of the factor analysis with the aim of revealing the aim or source of variation among many observed categories and sub-categories concerning symbolic play of pre-school children as complex research variable. The model includes five factors which confirm the thesis that symbolic play represents the basis of imagination and creativity development, as well as conformity.

Key words: symbolic play, creativity, conformity. 